\title{
ANALISIS KINERJA ORGANISASI MELALUI KEPEMIMPINAN TRANSFORMASIONAL DAN BUDAYA ORGANISASI
}

\author{
Sri Wartini \\ Fakultas Ekonomi Universitas Negeri Semarang \\ Email: sriwartini169@gmail.com
}

\begin{abstract}
ABSTRAK
Kinerja organisasi menjadi peranan penting sebagai tolok ukur keberhasilan sebuah organisasi atau perusahaan. Untuk mencapai kerberhasilan tersebut kinerja organisasi banyak dipengaruhi oleh berbagai faktor diantaranya adalah dari faktor kepemimpinan transformasional dan budaya organisasi itu sendiri. Tujuan penelitian ini untuk mengetahui pengaruh dari kedua faktor tesebut terhadap kinerja organisasi. Populasi penelitian ini adalah seluruh karyawan Perum Bulog Divre Jawa Tengah sejumlah 94 orang dengan teknik pengambilan sampel menggunakan total sampel. Bedasarkan olah data dengan program statistik SPSS versi 19.00 membuktikan bahwa pengujian hipotesis secara parsial untuk variabel kepemimpinan transformasional dan budaya organisasi terbukti berpengaruh terhadap kinerja organisasi, ini menjelaskan bahwa semakin baik kepemimpinan dan budaya organisasi tersebut diterapkan, akan semakin dapat meningkatkan kinerja organisasi.Kontribusi kedua variabel bebas terhadap Kinerja organisasi dapat dilihat pada nilai $\mathrm{R}$ Square sebesar $33,1 \%$ dan sisanya dipengaruhi oleh variabel lain yang tidak dikaji dalam penelitian ini. Hal ini menunjukkan bahwa kepemimpinan dan budaya organisasi memiliki peran penting untuk keberhasilan dalam memotivasi kerja karyawan, yang akhirnya berdampak pada kinerja organisasi.
\end{abstract}

\section{PENDAHULUAN}

Persaingan dalam dunia bisnis sekarang ini sangat menuntut para pekerja lebih siap menghadapi tantangan-tantangan yang menghadang. Agar perusahaan tetap eksis maka harus berani menghadapi tantangan dan implikasinya yaitu menghadapi perubahan dan memenangkan persaingan. Sumber daya yang dimiliki oleh perusahaan seperti modal, metode dan mesin tidak bisa memberikan hasil yang optimum apabila tidak didukung oleh sumber daya manusia yang mempunyai kinerja yang optimum (Rani 2009:1). Keberhasilan suatu organisasi juga ditentukan oleh kepemimpinan yang dikembangkan pada organisasi itu, serta komitmen karyawan yang tinggi terhadap organisasi tersebut dapat membawa organisasi mencapai tujuan yang diharapkan.

Locke (1997 dalam Harsiwi, 2003:2 ) melukiskan kepemimpinan sebagai suatu proses membujuk (inducing) orang-orang lain menuju sasaran bersama. Definisi tersebut mencakup tiga elemen yaitu Kepemimpinan merupakan suatu konsep relasi (relational concept), kepemimpinan merupakan suatu proses dan kepemimpinan harus membujuk orang-orang lain untuk mengambil tindakan.

Seorang karyawan dinilai produktif bila mampu menghasilkan sesuatu aktivitas pekerjaan yang sesuai dengan standar yang telah ditentukan oleh perusahaan. Faktor penentu yang berpengaruh dalam pencapaian tingkat produktifitas yang tinggi oleh seorang karyawan diantaranya adalah komitmen dan kinerja dari karyawan tersebut terhadap organisasi yang mereka naungi. Oleh karena itu untuk menjaga dan meningkatkan komitmen organisasi dan kinerja karyawan, perusahaan diharapkan dapat memperhatikan kepemimpinan transformasional dan budaya organisasi dalam perusahaan tersebut. Kepemimpinan transformasional yang syarat pada asumsi, norma, dan nilai-nilai tidak menghalangi karyawan dalam mengejar tujuan dan manfaat para karyawan, bahkan dengan kepemimpinan transformasional dapat memberi semangat pada karyawan untuk berkerja lebih giat (Chen, 
2004:3). Karena dengan adanya perubahan yang terjadi pada dalam organisasi para karyawan akan terpacu untuk bekerja keras mencapai tujuan-tujuan yang diharapkan organisasi tersebut.

Pada dasarnya para pemimpin secara riil harus mampu mengarahkan organisasi menuju arah baru (Locke, dalam Harsiwi, 2003:4). Kepemimpinan transformasional diharapkan dapat memotivasi bawahannya agar dapat bekerja dengan lebih giat sehingga dapat mencapai tujuan organisasi yang diinginkan.

Budaya organisasi dan kepemimpinan telah secara independen dihubungkan dengan kinerja perusahaan. Para peneliti telah menguji hubungan antara gaya kepemimpinan dan kinerja (Bass et.al, 1993 dalam Rani, 2009:15) dan juga antara budaya perusahaan dan kinerja (Abdul Rashid et.al, 2003 dalam Rani, 2009:15)

Bass dan Avolio (1993) dan Schein (2004) dalam Nurjanah (2008:20) menyatakan bahwa seorang pemimpin membentuk budaya dan pada gilirannya dibentuk oleh budaya yang dihasilkan Budaya organisasi pada dasarnya dapat mempengaruhi seseorang dalam pembentukan kepribadian dan pencapaian tujuan, tanggung jawab dan potensi sumber daya manusia yang dimiliki. Budaya organisasi dapat menjadi kekuatan positif dan negative, berfikir dalam mengambil suatu keputusan dalam mencapai prestasi organisasi yang berupa penerimaan, perasaan, dan tindakan.

Banyak pakar menyebutkan bahwa budaya organisasi dapat menjadi basis adaptasi dan kunci keberhasilan organisasi sehingga banyak penelitian dilaku kan untuk mengidentifikasi nilai-nilai atau norma-norma perilaku yang bisa memberikan kontribusi besar bagi keberhasilan organisasi (Abdul Rashid et.al, 2003 dalam Rani 2009:15). Namun relatif sedikit yang mencoba menghubungkan budaya organisasi dengan variabel-variabel sumber daya manusia yang penting, khususnya kinerja karyawan (Pool 2000, dalam Rani 2009:15)

Kinerja menurut Winardi (1992 dalam Puspita, 2008:13) adalah suatu konsep yang bersifat universal yang merupakan efektifitas operasional suatu organisasi, bagian organisasi dan bagian karyawannya berdasarkan standard an criteria yang telah ditetapkan sebelumnya, karena organisasi pada dasarnya dijalankan oleh manusia dalam memainkan peran yang mereka lakukan di dalam suatu organisasi untuk memenuhi suatu standar perilaku yang telah ditetapkan agar membuahkan tindakan dan hasil yang diinginkan. Salah satu indikator dari standar perilaku dalam suatu kinerja adalah kedisiplinan dalam kehadiran, karena dengan kehadiran membuktikan aktion dari sebuah komitmen kerja karyawan.

Ketidakhadiran atau keterlambatan karyawan didalam bekerja juga dapat mempengaruhi tingkat kinerja karyawan, berdasarkan standar kerja yang telah ditetapkan dalam Sistem Manajemen Kerja dari perusahaan, kondisi aktual tidak sesuai dengan kondisi normal yang diharapkan perusahaan. Dapat dijelaskan bahwa jika karyawan tidak hadir atau terlambat dalam bekerja maka tugas yang dibebankan kepadanya akan terbengkalai atau tidak sesuai dengan yang diharapkan. Dan hal ini akan menimbulkan ketidakefektifan seseorang dalam bekerja, lebih jauh lagi terjadi penurunan kinerja. Untuk jangka panjang hal ini akan berdampak terhadap kinerja organisasi. Cuti kerja merupakan hak setiap karyawan yang diberikan oleh organisasi, tetapi jika cuti kerja yang dilakukan terlalu lama juga akan berdampak terhadap kinerja karyawan.

Oleh karena itu diperlukan sikap atau gaya kepemimpinan transformasional yang cocok untuk situasi yag lain, dan juga agar budaya organisasi yang baik dapat selalu dipertahankan, serta menghilangkan budaya-budaya organisasi yang buruk. Permasalahan dalam penelitian ini untuk menjelaskan bagimanakah pengaruh kepemimpinan transformasional dan budaya organisasi mempengaruhi kinerja organisasi. Adapun tujuan penelitian ini untuk mengetahui Pengaruh kepemimpinan transformasional dan budaya organisasi terhadap kinerja organisasi 


\section{TINJAUAN PUSTAKA}

\section{Kinerja}

Istilah kinerja berasal dari kata job performance atau actual performance yang berarti prestasi kerja atau prestasi sesungguhnya yang dicapai oleh seseorang. Biasanya orang yang kinerjanya tinggi disebut sebagai orang yang produktif, dan sebaliknya orang yang tingkat kinerjanya tidak mencapai standar dikatakan sebagai orang yang tidak produktif atau berperforma rendah.

Menurut Selamet (2009:236) Prestasi kerja atau Kinerja (Performance management system) merupakan proses yang digunakan untuk mengidentifikasi, mendorong, mengukur, mengevaluasi, meningkatkan dan memberikan penghargaan terhadap kinerja pekerja. Pada dasarnya kinerja merupakan perilaku manusia dalam memainkan peran yang mereka lakukan di dalam suatu organisasi untuk memenuhi suatu standar perilaku yang telah ditentukan agar membuahkan tindakan dan hasil yang diinginkan.

Pemikiran kinerja karyawan menurut Mangkunegara (2005:9) adalah hasil kerja secara kualitas dan kuantitas yang dicapai seseorang karyawan dalam melaksanakan tugasnya sesuai dengan tanggung jawab yang diberikan kepadanya. Kinerja karyawan adalah hasil dari proses pekerjaan tertentu secara berencana pada waktu dan tempat dari karyawan serta organisasi bersangkutan menurut Mangkuprawira dan Hubeis (2007:153). Berdasarkan uraian yang telah dikemukakan, maka kinerja karyawan adalah kontribusi karyawan atau hasil proses pekerjaan kepada organisasi.

Berhasil atau tidaknya kinerja yang telah dicapai oleh suatu organisasi, dipengaruhi oleh tingkat kinerja dari karyawan, baik secara individual maupun secara kelompok. Dengan asumsi bahwa semakin baik kinerja karyawan, maka diharapkan kinerja organisasi akan semakin baik. Sehubungan dengan hal tersebut, maka dalam penelitian ini pendekatan untuk mengukur sejauh mana kinerja karyawan secara individual ada 6 kriteria yaitu (Bernardin, dalam Robbins, 1996:260):

Kualitas, Tingkat dimana hasil aktivitas yang dikehendaki mendekati sempurna dalam arti menyesuaikan beberapa cara ideal dari penampilan aktivitas, maupun memenuhi tujuantujuan yang diharapkan dari suatu aktivitas. Kualitas kerja diukur dari persepsi pegawai terhadap kualitas pekerjaan yang dihasilkan serta kesempurnaan tugas terhadap ketrampilan dan kemampuan pegawai.

Kuantitas, Merupakan jumlah yang dihasilkan dinyatakan dalam istilah seperti jumlah unit, jumlah siklus aktivitas yang diselesaikan. Kuantitas yang diukur dari persepsi pegawai terhadap jumlah aktivitas yang ditugaskan beserta hasilnya.

Ketepatan Waktu, Tingkat suatu aktivitas diselesaikan pada awal yang dinyatakan, dilihat dari sudut koordinasi dengan hasil output serta memaksimalkan waktu yang tersedia untuk aktivitas lain. Ketepatan waktu diukur dari persepsi pegawai terhadap suatu aktivitas yang diselesaikan di awal waktu sampai menjadi output.

Efektivitas, Tingkat penggunaan sumber daya organisasi (tenaga, uang, teknologi, bahan baku) dimaksimalkan dengan maksud menaikkan hasil dari setiap unit dalam penggunaan sumber daya. Efektivitas kerja persepsi pegawai dalam menilai pemanfaatkan waktu dalam menjalankan tugas, efektivitas penyelesaian tugas yang dibebankan organisasi.

Kemandirian, Adalah tingkat seorang pegawai dapat melakukan fungsi kerjanya tanpa minta bantuan, bimbingan dari orang lain atau pengawas. Kemandirian dapat diukur dari persepsi pegawai terhadap tugas dalam melakukan fungsi kerjanya masing-masing pegawai sesuai dengan tanggung jawab pegawai itu sendiri.

Komitmen kerja, Merupakan tingkat dimana pegawai mempunyai komitmen kerja dengan instansi dan tanggung jawab pegawai terhadap kantor. Pengukuran dengan menggunakan persepsi pegawai dalam membina hubungan dengan instansi serta tanggung jawab dan loyalitas pegawai. 


\section{Penilaian kinerja}

Jika perusahaan hanya berpegang pada asumsi bahwa orang tidak akan bekerja kecuali jika mereka diawasi dan dikendalikan dengan ketat, dirinya cenderung menerapkan cara penilaian yang obyektif. Oleh karena itu, laporan tentang kinerja karyawan merupakan laporan yang bersifat rahasia. Sebaliknya, jika perusahaan mempunyai pandangan bahwa setiap individu akan bekerja sesuai dengan potensinya dan kekuatan-kekuatannya dan bahwa kemampuan-kemampuan manusia dapat ditambah atau dikembangkan, perusahaan akan mengusahakan suatu sistem penilaian yang berusaha mengenali, memperjelas, mengembangkan dan memanfaatkan potensi dan kemampuan-kemampuan para karyawan (Rivai, 2004:308).

Penilaian Kinerja menurut Slamet (2009:236) adalah proses evaluasi seberapa baik seorang pekerja mengerjakan pekerjaan mereka ketika dibandingkan dengan suatu standard kemudian mengkomunikasikannya dengan para pekerja. Dalam sebuah organisasi menilai suatu pekerjaan para pegawai merupakan salah satu tugas manajer. Menilai kinerja seorang karyawan tidak dapat mendapatkan hasil yang akurat, sebab sifat maupun cara penilaian kinerja tergantung pada bagaimana sumber daya manusia dipandang dan diperlakukan di dalam perusahaan tersebut.

Menurut Soeprihanto (1998, dalam Puspita, 2008:20) Manfaat Kinerja Kontribusi hasilhasil penilaian merupakan suatu yang sangat bermanfaat bagi perencanaan kebijakan organisasi adapun secara terperinci penilaian kinerja bagi organisasi adalah: 1) Penyesuaianpenyesuaian kompensasi, 2) Perbaikan kinerja, 3) Kebutuhan latihan dan pengembangan, 4) Pengambilan keputusan dalam hal penempatan promosi, mutasi, pemecatan, pemberhentian dan perencanaan tenaga kerja, 5) Untuk kepentingan penelitian pegawai, 6) Membantu diagnosa terhadap kesalahan desain pegawai.

\section{Kepemimpinan Transformasional}

Robbins (2006:90) mendefinisikan kepemimpinan transformasional yaitu pemimpin yang menginspirasi para pengikutnya untuk mengenyampingkan kepentingan pribadi mereka demi kebaikan organisasi dan mereka mampu memiliki pengaruh yang luar biasa pada diri para pengikutnya. Kepemimpinan transformasional adalah pemimpin yang memberikan motivasi kepada karyawan untuk bekerja keras mencapai tujuan-tujuan yang lebih tinggi (Sunarto,2005:34, dalam Dwi, 2008:30).

Gaya kepemimpinan yang ditampilakan seorang pemimpin yang transformasional diharapkan dapat meningkatkan upaya bawahan untuk mencapai hasil kerja yang optimal, di mana gaya kepemimpinan transformasional merupakan salah satu gaya kepemimpinan yang mulai diperhitungkan kegunaannya dalam menghadapi perubahan suatu organisasi(Mujiasih dan Hadi, 2003:199, dalam Dwi, 2008:30)

Kepemimpinan transformasional merupakan gaya kepemimpinan yang dilakukan oleh seseorang manajer bila ia ingin suatu kelompok melebarkan batas dan memiliki kinerja melampaui status quo atau mencapai serangkaian sasaran organisasi yang sepenuhnya baru. Kepemimpinan transformasional pada prinsipnya memotivasi bawahannya untuk berbuat lebih baik dari apa yang bisa dilakukan, dengan kata lain dapat meningkatkan kepercayaan atau keyakinan diri bawahan yang akan berpengaruh terhadap peningkatan kinerja (O'Leary dalam Dwi, 2008:30)

Kepemimpinan Tranformasional memotivasi karyawan untuk melakukan pekerjaan atau tugas lebih baik dari apa yang bawahan inginkan dan bahkan lebih tinggi dari apa yang sudah diperkirakan sebelumnya. Menurut Hartanto kepemimpinan sperti ini akan sejak awal menimbulkan kesadaran dan komitmen yang tinggi dari kelompok terhadap tujuan dan misi organisasi serta akan meningkatkan kinerja organisasi sesuai dengan ketercapaian tujuan perusahaan. 
Bass (dalam Stefanus 2007:51) mengemukakan beberapa dimensi kepemimpinan transformasional, yaitu:

1. Individualized influence melalui model-model aturan bagi pengikut, yang mana pengikut mengidentifikasi dan ingin melakukan melebihi model tersebut. Pemimpin-pemimpin menunjukkan standar tinggi dari tingkah laku moral dan etika, serta menggunakan kemampuan untuk menggerakkan individu maupun kelompok terhadap pencapaian misi mereka dan bukan untuk nilai perorangan.

2. Inspirational motivation, pemimpin memberikan arti dan tantangan bagi pengikut dengan maksud menaikkan semangat dan harapan, menyebarkan visi, komitmen pada tujuan dan dukungan tim.

3. Intellectual stimulation, pemimpin transformasional menciptakan rangsangan dan berfikir inovatif bagi pengikut melalui asumsi-asumsi pertanyaan, merancang kembali masalah, menggunakan pendekatan pada situasi lampau melalui cara yang baru.

4. Individualized consideration melalui pemberian bantuan sebagai pemimpin, memberikan pelayanan sseebagai mentor, memeriksa kebutuhan individu untuk perkembangan dan peningkatan keberhasilan.

Dengan demikian pemimpin memainkan peranan yang penting dan sangat dibutuhkan, baik oleh perusahaan maupun bawahan. Pimpinan merupakan pihak yang menentukan dan pengambil keputusan yang paling utama yang berhubungan dengan kebijaksanaan perusahaan. Kepemimpinan transformasional juga dapat mengubah budaya organisasi mereka dengan visi baru dan revisi nilai-nilai syarat asumsi dan norma-norma (Bass, 1985, dalam Chen, 2004:436). Dalam budaya yang transformasional, umumnya ada rasa tujuan dan perasaan kekeluargaan. Atasan merasa kewajiban pribadi untuk membantu anggota baru berasimilasi ke dalam budaya. Asumsi, norma, dan nilai-nilai tidak menghalangi individu dari mengejar tujuan mereka sendiri dan manfaat. Pemimpin dan pengikutnya berbagi kepentingan bersama dan ada rasa senasib dan ketergantungan. Dengan begitu yang menjadi indikator kepemimpinan transformasional yaitu kharisma, motivasi inspirasional, intelektual simulasi, konsiderasi individual.

Dengan merujuk dasar teori kepemimpinan Transformasional yang memberikan kontribusi pada kinerja organisasi, maka hipotesis yang diajukan adalah

H1: Kepemimpinan Transformasional berpengaruh terhadap Kinerja Organisasi

\section{Budaya Organisasi}

Budaya organisasi merupakan faktor yang paling kritis dalam organisasi. Efektivitas organisasi dapat ditingkatkan dengan menciptakan budaya yang kuat, yang dapat digunakan untuk mencapai tujuan organisasi. Organisasi yang berbudaya kuat akan memiliki ciri khas tertentu sehingga dapat memberikan daya tarik bagi individu untuk bergabung. Suatu budaya yang kuat merupakan perangkat yang sangat bermanfaat untuk mengarahkan perilaku, karena membantu karyawan untuk melakukan pekerjaan dengan lebih baik, sehingga setiap karyawan perlu memahami budaya dan bagaimana budaya tersebut terimplementasikan.(Nurjanah, 2008:35)

Menurut Griffin dan Ebbert (1996:11) dari kutipan umar Nimran dalam Eko (2009:16), Budaya organisasi atau bisa diartikan sebagai "pengalaman, sejarah, keyakinan dan Normanorma bersama yang menjadi ciri perusahaan atau organisasi". Budaya organisasi merupakan sistem nilai-nilai, keyakinan dan norma-norma yang unik, dimiliki secara bersama oleh anggota suatu organisasi (Gibson et al, 1996:42, dalam Eko, 2009:16). Hofstede (1994:4) budaya organisasi merupakan pola pemikiran, perasaan dan tindakan dari suatu kelompok sosial, yang membedakan dengan kelompok sosial yang lain.

Kottler dan Haskett (1992:54) menyatakan bahwa budaya dalam organisasi merupakan nilai yang dianut bersama oleh anggota organisasi, cenderung membentuk perilaku kelompok. 
Nilai-nilai sebagai budaya organisasi cenderung tidak terlihat maka sulit berubah. Norma perilaku kelompok yang dapat dilihat, tergambar pada pola tingkah laku dan gaya anggota organisasi relative dapat berubah.

"Budaya organisasi merupakan faktor yang dapat meningkatkan kinerja", Chatman dan Bersade(1997) dan Udan Bintoro (2002) dalam Guestina (2007:35) menyatakan bahwa budaya organisasi yang kuat mampu meningkatkan kinerja organisasi. Budaya organisasi yang diciptakan oleh pemimpin akan berpengaruh terhadap aplikasi strategis dan keberhasilan perusahaan juga terhadap kinerja karyawan.

Dari pengertian diatas dapat disimpulkan bahwa budaya organisasi dapat mempengaruhi seseorang dalam pembentukan kepribadian seseorang dan pencapaian tujuan, tanggung jawab dan potensi sumber daya yang dimiliki. Budaya organisasi dapat menjadi kekuatan positif dan negative, berfikir dalam mengambil suatu keputusan dalam mencapai prestasi organisasi yang berupa penerimaan, perasaan, dan tindakan.

\section{Dimensi-dimensi Budaya-budaya Organisasi}

Luthans (1998 dalam Sopiah, 2008:129-130) menyebutkan sejumlah karakteristik yang penting dari budaya organisasi, yang meliputi: Pertama, Aturan-aturan perilaku seperti bahasa, terminology dan ritual yang biasa dipergunakan oleh anggota organisasi. Kedua, Norma merupakan standar perilaku yang meliputi petunjuk bagaimana melakukan sesuatu. Lebih jauh di masyarakat kita kenal adanya norma agama, norma sosial, norma susila, norma adat. Ketiga, Nilai-nilai dominan seperti nilai yang diharapkan dari organisasi untuk dikerjakan oleh para anggota, misalnya tingginya kualitas produk, rendahnya tingkat absensi, tingginya produktivitas dan efisiensi, serta tingginya disiplin kerja. Keempat, Filosofi dimana kebijakan yang dipercaya organisasi tentang hal-hal yang disukai para karyawan dan pelanggannya, seperti "kepuasan anda adalah harapan kami","konsumen adalah raja. Kelima, Peraturan-peraturan yaitu aturan yang tegas dari organisasi. Pegawai baru harus memelajari peraturan ini agar keberadaannya dapat diterima di dalam organisasi. Keenam, Iklim organisasi yang merupakan keseluruhan "perasaan" yang meliputi hal-hal fisik, bagaimana para anggota berinteraksi dan bagaimana para anggota organisasi mengendalikan diri dalam berhubungan dengan pelanggan atau pihak luar organisasi.

Terdapat tujuh dimensi yang merupakan hakikat dari budaya organisasi menurut Robbin (2006:256), yaitu:

1. Inovasi dan keberanian mengambil risiko, artinya sejauh mana para karyawan didorong untuk bersikap inovatif dan mengambil risiko.

2. Perhatian terhadap detail, artinya sejauh mana karyawan diharapkan memperlihatkan kecermatan, analisis dan perhatian terhadap detail.

3. Orientasi hasil, artinya sejauh mana para manajemen memusatkan perhatian pada hasil bukannya pada tehnik dan proses-proses yang digunakan untuk mencapai hasil-hasil itu.

4. Orientasi orang, artinya sejauh mana keputusan-keputusan manajemen memperhitungkan pengaruh hasil-hasil terhadap manusia didalam organisasi.

5. Orientasi tim, artinya sejauh mana kegiatan kerja diorganisasikan berdasarkan tim, bukan berdasarkan individu.

6. Keagresifan, artinya sejauh mana orang bersifat agresif dan kompetitif ketimbang santai.

7. Stabilitas, artinya sejauh mana kegiatan organisasi menekankan dipertahankannya status quo dalam perbandingannya dengan pertumbuhan.

Dengan demikian budaya organisasi merupakan suatu sistem nilai yang diperoleh dan dikembangkan oleh organisasi yang sudah ada sejak organisasi itu terbentuk dan menjadi aturan yang digunakan sebagai pedoman dalam berfikir dan bertindak dalam mencapai tujuan organisasi. Dalam penelitian Gustina (2007:35) membuktikan pendapat Robin (2006) yaitu 
ada pengaruh variable budaya organisasi terhadap kinerja karyawan. Begitu pula penelitian Udan Bintoro (2002) menyatakan bahwa budaya organisasi yang kuat mampu meningkatkan kinerja organisasi melalui indikator dari budaya organisasi yaitu inovasi dan keberanian mengambil resiko, perhatian terhadap detail, orientasi hasil, orientasi orang, orientasi tim, keagresifan, dan stabilitas.

Merujuk keterkaitan teori tersebut maka hipotesis yang diajukan adalah:

H2: Budaya Organisasi berpengaruh terhadap kinerja organisasi

Dengan melihat keterkaitan kepemimpinan transformasional dan budaya organisasi terhadap kinerja organisasi tersebut maka dapat digambarkan model berpikir penelitian seperti pada gambar 1 .

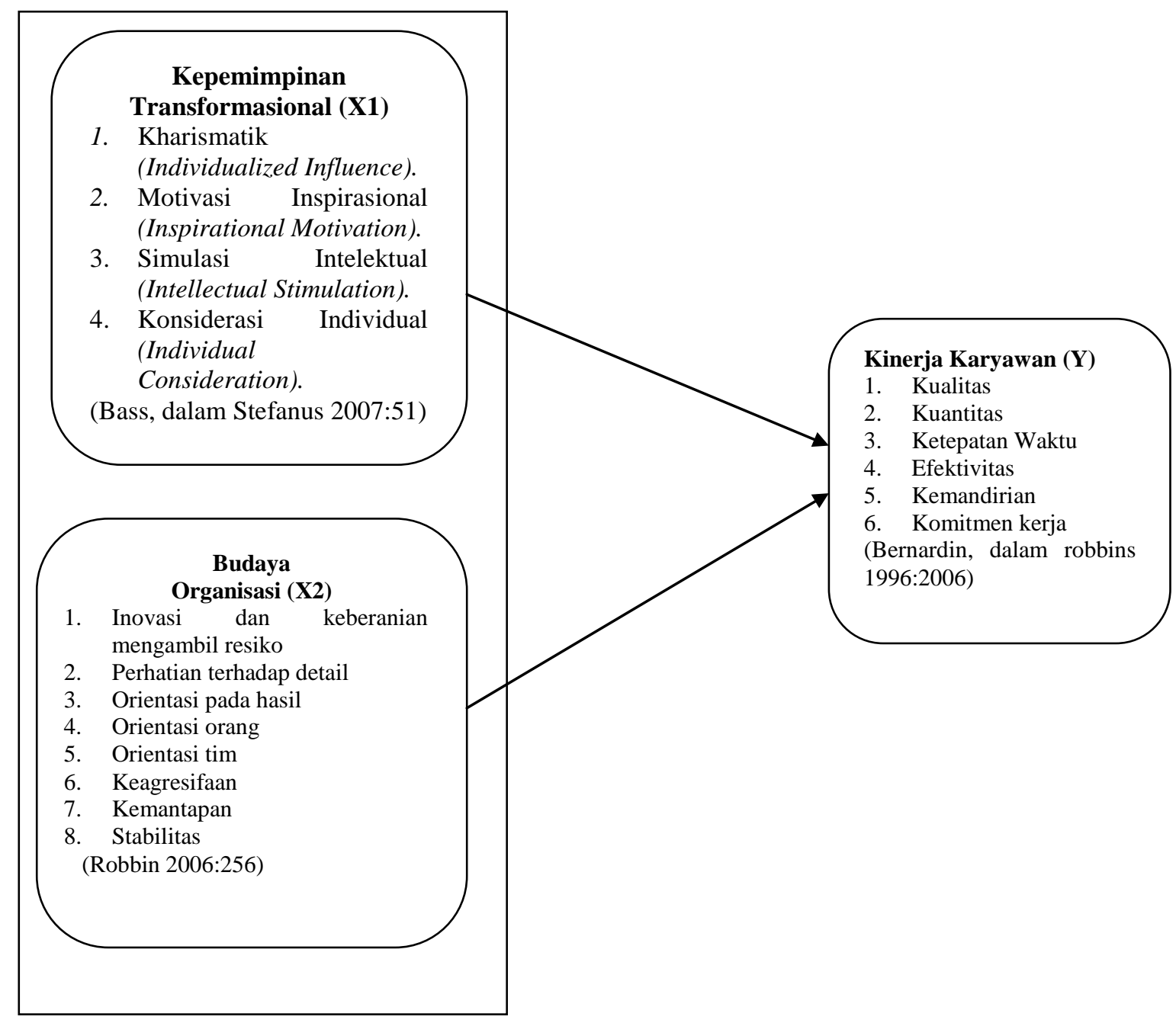

Gambar 1

Model berfikir 


\section{METODE PENELITIAN}

Populasi penelitian ini adalah seluruh karyawan Perum Bulog Divre Jawa Tengah yaitu 94 orang. Dengan teknik pengaabilan sampel menggunakan total sampling yaitu seluruh populasi menjadi anggota yang akan dianalisis sebagai sampel.

Data primer dalam penelitian ini adalah hasil jawaban responden terhadap kuesioner variabel kepemimpinan transformasional, budaya organisasi, dan kinerja karyawan. Data sekunder dalam penelitian ini adalah daftar laporan berupa jumlah karyawan perusahaan, sejarah perusahaan, dan struktur organisasi.

Metode pengumpulan data menggunakan data dokumentasi berupa nama dan jumlah staff, uraian tugas dan wewenang, data absensi dan sebagainya yang dibutuhkan, yang berada di lingkungan Perum Bulog Divre Jateng dan data hasil jawaban responden dari kuesioner yang diberikan . Untuk jawaban alternative sudah disediakan dan hanya membutuhkan waktu yang lebih singkat untuk menjawabnya. Untuk mengukur hasil tanggapan responden, maka digunakan skala. Skala yang digunakan dalam penelitian ini adalah skala Likert, dimana jawaban yang mendukung pertanyaan diberi skor yang tinggi sedangkan untuk jawaban yang tidak atau kurang mendukung diberi skor rendah.

Variabel dalam penelitian ini meliputi variabel kepemimpinan transfomasional dengan indikator Karismatik, Motivasi Inspirasional, Simulasi Intelektual, dan Konsiderasi Individual (Bass, dalam Stefanus 2007). Untuk variabel Budaya organisasi didukung dengan indikator Inovasi dan keberanian mengambil resiko, Perhatian terhadap detail, Orientasi pada hasil, Orientasi orang

Keagresifaan, dan Stabilitas. Dan untuk variabel Kinerja organisasi didukung dengan indikator Kualitas, Kuantitas, Ketepatan waktu, Efektivitas, Kemandirian dan Komitmen kerja.

\section{HASIL DAN PEMBAHASAN}

Hasil pengujian validitas dari 33 intrumen penelitian dengan program SPSS. Versi 19.00 dapat dilihat pada tabel berikut ini:

Tabel 1. Hasil Uji Validitas Variabel Kepemimpinan Transformasional

\begin{tabular}{cccc}
\hline $\begin{array}{c}\text { Item } \\
\text { pertanyaan }\end{array}$ & $\mathrm{R}_{\text {hitung }}$ & $\mathrm{R}_{\text {table }}$ & Keterangan \\
\hline P1 & 0,549 & 0,444 & Valid \\
P2 & 0,591 & 0,444 & Valid \\
P3 & 0,595 & 0,444 & Valid \\
P4 & 0,527 & 0,444 & Valid \\
P5 & 0,603 & 0,444 & Valid \\
P6 & 0,772 & 0,444 & Valid \\
P7 & 0,620 & 0,444 & Valid \\
P8 & 0,638 & 0,444 & Valid \\
P9 & 0,521 & 0,444 & Valid \\
\hline
\end{tabular}

Sumber: Data penelitian yang diolah, 2013 


\begin{tabular}{cccc} 
Tabel 2. Hasil Uji Validitas Variabel Budaya Organisasi & \\
\hline Item pertanyaan & $\mathrm{R}_{\text {hitung }}$ & $\mathrm{R}_{\text {table }}$ & Keterangan \\
\hline P10 & 0,445 & 0,444 & Valid \\
P11 & 0,558 & 0,444 & Valid \\
P12 & 0,466 & 0,444 & Valid \\
P13 & 0,611 & 0,444 & Valid \\
P14 & 0,531 & 0,444 & Valid \\
P15 & 0,455 & 0,444 & Valid \\
P16 & 0,571 & 0,444 & Valid \\
P17 & 0,489 & 0,444 & Valid \\
P18 & 0,762 & 0,444 & Valid \\
P19 & 0,583 & 0,444 & Valid \\
P20 & 0,811 & 0,444 & Valid \\
P21 & 0,764 & 0,444 & Valid \\
P22 & 0,675 & 0,444 & Valid
\end{tabular}

Sumber: Data penelitian yang diolah, 2013

Table 3. Hasil Uji Validitas Variabel Kinerja Karyawan

\begin{tabular}{cccc}
\hline $\begin{array}{c}\text { Item } \\
\text { Pertanyaan }\end{array}$ & $\mathrm{R}_{\text {hitung }}$ & $\mathrm{R}_{\text {table }}$ & Keterangan \\
\hline P23 & 0,544 & 0,444 & Valid \\
P23 & 0,612 & 0,444 & Valid \\
P25 & 0,580 & 0,444 & Valid \\
P26 & 0,754 & 0,444 & Valid \\
P27 & 0,521 & 0,444 & Valid \\
P28 & 0,492 & 0,444 & Valid \\
P29 & 0,661 & 0,444 & Valid \\
P30 & 0,492 & 0,444 & Valid \\
P31 & 0,704 & 0,444 & Valid \\
P32 & 0,485 & 0,444 & Valid \\
P33 & 0,754 & 0,444 & Valid \\
\hline
\end{tabular}

Sumber: Data penelitian yang diolah, 2013

Berdasarkan tabel hasil uji validitas di atas maka seluruh item pertanyaan dari variabel kepemimpinan transformasional, budaya organisasi dan kinerja organisasi terbukti valid dimana Semua nilai $R$ hitung $>\mathrm{R}$ tabel yang ditetapkan sebesar 0,444.

Hasil pengujian reliabilitas dari variabel kepemimpinan transfomasional, budaya organisasi dan kinerja organisasi dengan program SPSS versi 19.00 dapat dilihat pada tabel 4 .

Tabel 4. Hasil Uji Reliabilitas Variabel Penelitian

\begin{tabular}{lccc}
\hline \multicolumn{1}{c}{ Variabel } & $\begin{array}{c}\text { Cronbach's } \\
\text { Alpha }\end{array}$ & $\begin{array}{c}\text { Cronbach's } \\
\text { Alpha } \\
\text { yang } \\
\text { disyaratkan }\end{array}$ & Kesimpulan \\
\hline $\begin{array}{l}\text { Kepemimpinan } \\
\text { Transformasional }\end{array}$ & 0,867 & 0,60 & Reliabel \\
$\begin{array}{l}\text { Budaya Organisasi } \\
\text { Kinerja Organisasi }\end{array}$ & 0,879 & 0,60 & Reliabel \\
\hline
\end{tabular}

Sumber: Data penelitian yang diolah, 2013 
Berdasarkan hasil uji reliabilitas menunjukkan bahwa semua variabel penelitian seperti variabel kepemimpinan trasfomasional, budaya organisasi dan kinerja organisasi terbukti reliabel, dimana nilai Cronbach's Alpha hitung > cronnbah's alpha yang ditetapkan sebesar 0,60. berikut ini:

Berdasarkan hasil uji regresi dengan progam SPSS dapat dilihat seperti pada tabel 5

\begin{tabular}{|c|c|c|c|c|c|}
\hline \multirow{3}{*}{ Model } & \multicolumn{4}{|c|}{ Table 5. Hasil Analisis Regresi } & \multirow{3}{*}{ Sig } \\
\hline & \multicolumn{2}{|c|}{$\begin{array}{l}\text { Unstandardized } \\
\text { Coefficients }\end{array}$} & $\begin{array}{l}\text { Standardized } \\
\text { Coefficients }\end{array}$ & $\mathrm{t}$ & \\
\hline & B & Std.Error & Beta & & \\
\hline 1. (Constant) & 13.952 & 4.970 & & 2.807 & .006 \\
\hline Kemimpinan & .204 & 0.82 & .240 & 2.489 & .015 \\
\hline $\begin{array}{l}\text { Transformasional } \\
\text { Budaya } \\
\text { Organisasi }\end{array}$ & .185 & 0.86 & .215 & 2.146 & .035 \\
\hline
\end{tabular}

a. Dependent Variable: Kinerja Organisasi

Dilihat dari hasil analisis regresi berganda di atas maka dapat dibuatkan persamaan regresi sebagai berikut $Y=13,952+0,204 X 1+0,185 X 2$

Hasil ini menunjukkan bahwa masing-masing nilai variabel penelitian menunjukan arah yang positif, hal ini memberikan makna bahwa setiap terjadi kenaikan variabel kepemimpinan transformasional dan budaya organisasi akan diikuti dengan peningkatan kinerja organisasi.

Sedangkan untuk pengujian hipotesis dapat diketahui bahwa nilai $\mathrm{t}$ hitung dari variabel kepemimpinan transformasional sebesar 2,489 dengan nilai Signifikansi $0,015<0,05$ ini berarti hipotesis yang menyatakan kepemimpinan transformasional berpengaruh terhadap kinerja organisasi adalah diterima. Penerimaan hipotesis ini dapat dijelaskan bahwa Kepemimpinan transformasional pada dasarnya memotivasi karyawan untuk melakukan pekerjaan atau tugas lebih baik dari apa yang bawahan inginkan. Apabila dalam sebuah organisasi terdapat gaya kepemimpinan yang transformasional maka sudah pasti karyawan akan terpacu untuk berkerja dengan lebih baik lagi sehingga akan dicapai hasil yang maksimal. Hal ini menggambarkan bahwa karyawan merasa pemimpin telah memerankan tugasnya dengan tepat, baik dari segi kepemimpinan yang kharisma, mampu memberikan motivasi dan inspirasi, memberikan dukungan, dan perhatian terhadap semua karyawan. Hasil ini mendukung temuan Stefanus (2007) yang membuktikan bahwa kepemimpinan transformasional dapat mempengaruhi kinerja karyawan.

Begitu pula untuk pengujian hipotesis variabel budaya organisasi diketahui nilai $\mathrm{t}$ hitung sebesar 2,146 dengan nilai signifikansi $0,035<0,05$ ini berarti bahwa hipotesis yang menyatakan budaya organisasi berpengaruh terhadap kinerja organisasi adalah diterima. Penerimaan hipotesis ini dapat dijelaskan bahwa Karyawan merasa budaya yang ada pada perusahaan dapat mendorong mereka bersikap inovatif dalam mengambil resiko yang mereka hadapi, yaitu dengan menyumbangkan ide-ide dalam rapat, berani menerima tantangan untuk tugas baru yang belum pernah diterima sebelumnya, mengkoreksi kembali hasil pekerjaan yang telah mereka kerjakan, dan karyawan selalu menepati waktu dalam melaksanakan tugas serta datang ke kantor dengan tepat waktu atau datang lebih awal. Hasil ini selaras dengan hasil penelitian Robin (2006) yang mebuktikan bahwa budaya organisasi berpengaruh secara langsung terhadap kinerja organisasi.

Kontribusi kedua variabel (Kepemimpinan ransformasional dan Budaya Organisasi) terhadap variabel Kinerja Organisasi dapat dilihat pada tabel hasil koefisien determinasi seperti pada tabel 6 . 
Tabel 6. Hasil Koefisien Determinasi

\begin{tabular}{cccccc}
\hline Model & $\mathrm{R}$ & $\begin{array}{c}\mathrm{R} \\
\text { Square }\end{array}$ & $\begin{array}{c}\text { Adjusted } \\
\mathrm{R} \\
\text { Square }\end{array}$ & $\begin{array}{c}\text { Stad Error Of } \\
\text { the Estimated }\end{array}$ & $\begin{array}{c}\text { Change } \\
\text { Statistic }\end{array}$ \\
\hline 1 & $.558^{\mathrm{a}}$ & .331 & .296 & 2.39426 & .000 \\
\hline
\end{tabular}

a.Predictors: (Constant) Budaya organisasi, Kepemimpinan Transformasional

b.Dependent Variabel : Kinerja Organisasi

Dari tabel tersebut dapat dijelaskan bahwa terbukti nilai $\mathrm{R}$ Square sebesar 0,331 atau $33,1 \%$ artinya Variabel kepemimpinan transformasional dan budaya organisasi telah memberikan kontribusi terhadap kinerja organisasi sebesar $33,1 \%$ sisanya $66,9 \%$ dipengaruhi oleh variabel lain yang tidak dikaji dalam penelitian ini.

\section{PENUTUP}

Berdasarkan hasil penelitian dan pembahasan, maka dapat disimpulkan bahwa kepemimpinan trasformasional mempunyai pengaruh terhadap kinerja organisasi artinya semakin baik kepemimpinan transformasional dijalankan maka akan semakin meningkatkan kinerja organisasi. Begitupula dengan budaya oranisasi terbukti bahwa budaya orgaisasi berpengaruh terhadap kinerja orgaisasi artinya semakin baik budaya organisasi itu diterapkan akan semakin dapat meningkatkan kinerja organisasi.

Implikasi manajerial yang bisa diberikan dari hasil penelitian ini hendaknya perusahaan dalam menerapkan kepemimpinan transformasional diperlukan adanya keterbukaan dan pengintegrasian dengan divisi-divisi yang lain sehingga peningkatan kinerja tidak hanya dirasakan pada satu divisi saja melainkan terintegrasi pada divisi lainnya.Implikasi teoritis untuk peneliti yang akan hendaknya bisa mengembangkan untuk meneliti variabel lain seperti sikap karyawan, rekan kerja, kepuasan, lingkungan organisasi atau lainnya sehingga diperoleh informasi secara lengkap terkait dengan faktor-faktor yang mempengaruhi kinerja.

\section{DAF TAR PUSTAKA}

Ardana, komang; Mujiati, Ni Wayan; Ayu Sriathi, Anak Agung. 2008. Perilaku Keorganisasian. Yogyakarta : Graha ilmu.

Ardiliscahyani, Putri. 2008. Pengaruh Budaya Organisasi Terhadap Komitmen Organisasi pada Karyawan di PT. Hutama Karya Wilayah IV Semarang. Penelitian Unnes Semarang

As'ad, Mohammad. 1987. Kepemimpinan yang Efektif dalam Perusahaan. Edisi Pertama. Liberty. Yogyakarta.

Gustina Amran, Tiena. 2007. Leadership and Organizational Culture Relationship Analysis On Job Performance and Satisfaction Using SEM(Structural Equation Modelling) At PT. Carita Boat Indonesia. Industrial Engineering Department, Trisakti University.

Ghozali, Imam. 2009. Aplikasi Analisis Multivariate dengan Program SPSS. Semarang: Badan Penerbit Universitas Diponegoro.

2005. Aplikasi Analisis Multivariate dengan Program SPSS. Semarang: Badan Penerbit Universitas Diponegoro. 
Handoko, T. Hani. 2001. Manajemen Edisi 2. Yogyakarta : BPFE

Mangkunegara, A. Prabu. 2005. Manajemen Sumber Daya Manusia Perusahaan. Bandung:PT. Remaja Rosdakarya.

Mangkuprawira, Sjafri dan Arda Vitayala Hubeis. 2007. Manajemen Mutu Sumber Daya Manusia. Cetakan Pertama. Ghalia Indonesia.

Nurjanah. 2008.Pengaruh Gaya Kepemimpinan dan Budaya Organisasi Terhadap Komitmen Organisasi Dalam Meningkatkan Kinerja Karyawan (Studi Pada Biro Lingkup Departemen Pertanian). Tesis Undip Semarang.

Rivai, Veithzal. 2004. Manajemen Sumber Daya Manusia untuk Perusahaan: Dari Teori ke Praktik. Jakarta: PT. Raja Grafindo Persada.

Rokhmawati, Puspita. 2008. Pengaruh Kepemimpinan dan Budaya Organisasi Terhadap Kinerja Karyawan Unit Spinning Pada PT. Sinar Pantja Djaja di Semarang. Penelitian Unnes Semarang

Slamet, Achmad. 2009. Manajemen Sumber Daya Manusia. Semarang: Universitas Negeri Semarang Press.

Sopiah. 2008.Perilaku Organisasi. Yogyakarta : ANDI

Stefanus Kaihatu, Thomas. 2007. Kepemimpinan Transformasional dan Pengaruhnya Terhadap Kepuasan atas Kualitas Kehidupan Kerja, Komitmen Organisasi, dan Perilaku Ekstra Peran: Studi pada Guru-Guru SMU di Kota Surabaya. Jurnal Ekonomi Manajemen, Universitas Kristen Petra.

Suprianti, Dwi. 2008. Pengaruh Kepemimpinan Transformasional dan Transaksional Terhadap Komitmen Organisasi Pada PT. Kereta Api Indonesia (Persero) DAOP IV Semarang. Penelitian Unnes

Sulistianto, Eko. 2009. Pengaruh Budaya Orgnaisasi, Gaya Kepemimpinan, Serta Kompensasi Terhadap Komitmen Organisasi Pegawai Dinas Perindustrian dan Perdagangan Jawa Tengah. Penelitian Unnes Semarang

Stephen, P. Robbins. 1996. Perilaku Organisasi: Konsep, Kontroversi, Aplikasi. Jilid kelima. Edisi Bahasa Indonesia. Jakarta: PT. Prenhalindo

2006. Perilaku Organisasi. Edisi Kesepuluh. Jakarta: PT. Indeks.

Umar, Husein. 2003. Metode Riset Perilaku Organisasi. Jakarta : Gramedia Pustaka Utama. Wibowo. 2006. Manajemen Perubahan. Jakarta: Rajagrafindo Persada.

Yueh Chen, Li. 2004. Examining the Effect of Organization Culture and Leadership Behaviors on Organizational Commitment, Job Satisfaction, and Job Performance at Small and Middle-sizad Firms of Taiwan. The Journal of American Academy of Business. Cambridge 